Article

\title{
Synthesis, Antimicrobial and Antioxidant Activities of 2-Isoxazoline Derivatives
}

\author{
Asma Alshamari ${ }^{1}$, Mahmoud Al-Qudah ${ }^{2, * \mathbb{D}}$, Fedaa Hamadeh ${ }^{2}$, Lo'ay Al-Momani ${ }^{3}$ (D) and \\ Sultan Abu-Orabi ${ }^{2}$ \\ 1 Department of Chemistry, Faculty of Science, University of Ha'il, P.O. Box. 2440, Ha'il 81451, Saudi Arabia; \\ aasmaalshamari@gmail.com \\ 2 Department of Chemistry, Faculty of Science, Yarmouk University, P.O. Box.566, Irbid 21163, Jordan; \\ mqudah74@gmail.com (F.H.); abuorabi@yu.edu.jo (S.A.-O.) \\ 3 Department of Chemistry, Tafila Technical University, P.O. Box. 179, Tafila 66110, Jordan; \\ loay1970@yahoo.com \\ * Correspondence: mahmoud.qudah@yu.edu.jo; Tel.: +962-7742-0029
}

Received: 20 August 2020; Accepted: 16 September 2020; Published: 18 September 2020

\begin{abstract}
A series of derivatives of trans-3-(2,4,6-trimethoxyphenyl)4,5-dihydroisoxazolo-4,5bis[carbonyl-(4' phenyl)thiosemicarbazide (9) and of trans-3-(2,4,6-trimethoxyphenyl)-4,5-dihydro isoxazolo-4,5-bis(aroylcarbohydrazide) (10a-c) were synthesized from trans-3-(2,4,6-trimethoxyphenyl)4,5-dihydro-4,5-bis(hydrazenocarbonyl)isoxazole (8). The structures of the compounds were elucidated by both elemental and spectral (IR, NMR, and MS) analysis. Compound 9 shows activity against some bacterial species. No antibacterial activities were observed for compounds $\mathbf{1 0 a}-\mathbf{c}$. The antioxidant activity of the new compounds has been screened. Compound 9 showed higher antioxidant activity using the DPPH (1,1-diphenyl-2-picrylhydrazyl) and ABTS (2'-azino-bis(3-ethylbenzoline- 6-sulfonic acid) diammonium salt methods.
\end{abstract}

Keywords: isoxazolines; nitrile oxide; 1,3-dipolar cycloaddition; antibacterial activity; antioxidant activity

\section{Introduction}

Isoxazolines are an important class of nitrogen- and oxygen-containing heterocycles that belong to the azoles family, and have gained great importance in the field of medicinal chemistry as anticancer agents [1-8]. They are also reported to possess good antimicrobial, analgesic, anti-inflammatory activities [4]. Several isoxazoline derivatives were generated by 1,3-dipolar cycloaddition of nitrile oxides. Abu-Orabi et al. reported that nitrile oxides $(\mathbf{1} \mathbf{a}$ and $\mathbf{1 b})$ reacted with dialkyl maleate $(\mathbf{2} \mathbf{a}$ and $\mathbf{2} \mathbf{b})$ to afford only the cis-cycloadducts $\mathbf{3 a - d}$; Scheme $1[9,10]$.<smiles>[R]OC(=O)/C=C\C(=O)O[R12]</smiles>

1a: $\mathrm{R}=\mathrm{OCH}_{3}$ 1b: $\mathrm{R}=\mathrm{CH}_{3}$ 2a: $\mathrm{R}_{1}=\mathrm{CH}_{3}$ 2b: $\mathrm{R}_{1}=\mathrm{C}_{2} \mathrm{H}_{5}$<smiles>[R17]OC(=O)C1ON=C(c2c([R])cc([R])cc2[R])C1C([R1])=O</smiles>

3a: $\mathrm{R}=\mathrm{OCH}_{3}, \mathrm{R}_{1}=\mathrm{CH}_{3}$

3b: $\mathrm{R}=\mathrm{OCH}_{3}, \mathrm{R}_{1}=\mathrm{C}_{2} \mathrm{H}_{5}$

3c: $\mathrm{R}=\mathrm{CH}_{3}, \mathrm{R}_{1}=\mathrm{CH}_{3}$

3d: $\mathrm{R}=\mathrm{CH}_{3}, \mathrm{R}_{1}=\mathrm{C}_{2} \mathrm{H}_{5}$

Scheme 1. The reaction of nitrile oxides $\mathbf{1} \mathbf{a}-\mathbf{b}$ with dialkyl maleate $\mathbf{2} \mathbf{a}-\mathbf{b}$ to obtain isoxazolines $\mathbf{3 a} \mathbf{a}-\mathbf{d}$. 
In contrast, the reaction of nitrile oxides $1 \mathbf{a}$ and $\mathbf{1 b}$ with dialkyl fumarate (4a and $4 \mathbf{b}$ ) yielded the trans-isomers 5a-d; Scheme 2 [9-11].

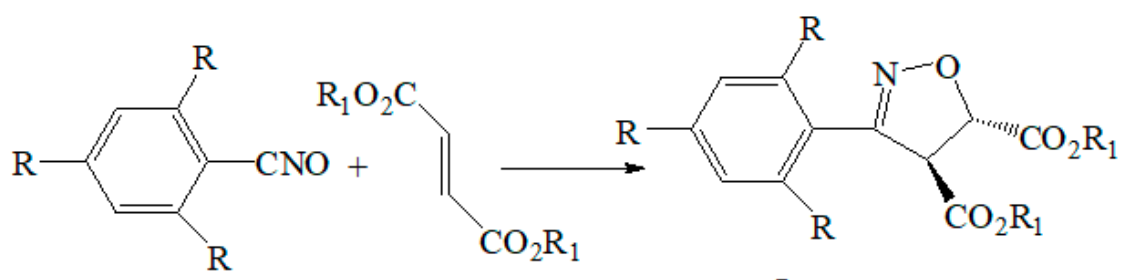
1a: $\mathrm{R}=\mathrm{OCH}_{3}$
4a: $\mathrm{R}_{1}=\mathrm{CH}_{3}$
1b: $: \mathrm{R}=\mathrm{CH}_{3}$
4b: $\mathrm{R}_{1}=\mathrm{C}_{2} \mathrm{H}_{5}$
5a: $\mathrm{R}=\mathrm{OCH}_{3}, \mathrm{R}_{1}=\mathrm{CH}_{3}$
5b: $\mathrm{R}=\mathrm{OCH}_{3}, \mathrm{R}_{1}=\mathrm{C}_{2} \mathrm{H}_{5}$
5c: $\mathrm{R}=\mathrm{CH}_{3}, \mathrm{R}_{1}=\mathrm{CH}_{3}$

Scheme 2. Synthesis of isoxazolines $5 \mathbf{a}-\mathbf{d}$ via 1,3-dipolar cycloaddition of nitrile oxides $\mathbf{1 a}-\mathbf{b}$ with dialkyl fumarate $\mathbf{4 a}-\mathbf{b}$.

Similarly, the reaction of compounds $\mathbf{1 a}$ and $\mathbf{1} \mathbf{b}$ with trans-dibenzoylethylene (6) was carried out to obtain the corresponding 2-isoxazoline derivatives $\mathbf{7 a}$ and $\mathbf{7 b}$ in good yields, as shown in Scheme 3 [11].

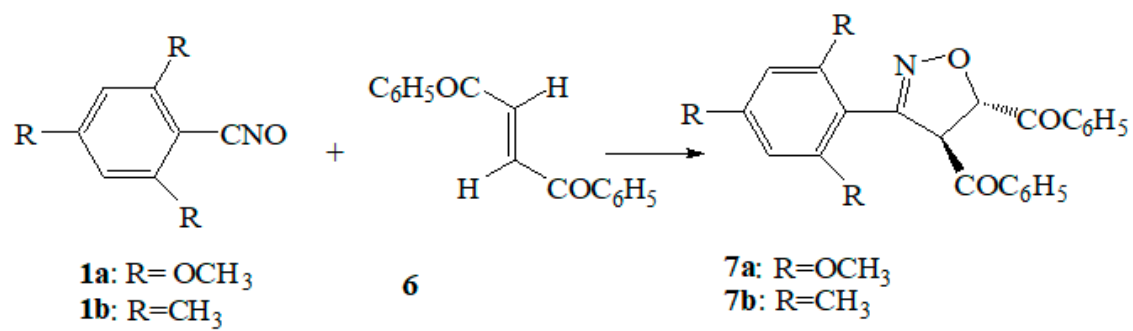

Scheme 3. 1,3-dipolar cycloaddition of nitrile oxides 1a-b with trans-dibenzoylethylene 6.

The isoxazoline derivatives $\mathbf{5 a - d}$ bearing an ester group were reacted with excess hydrazine hydrate in ethanol under reflux to give high yields of bis(hydrazinocarbonyl) derivatives $\mathbf{8 a}-\mathbf{b}$; Scheme 4 [12]. Isoxazole derivatives 5a-d showed antitrypanosomal activity [13].

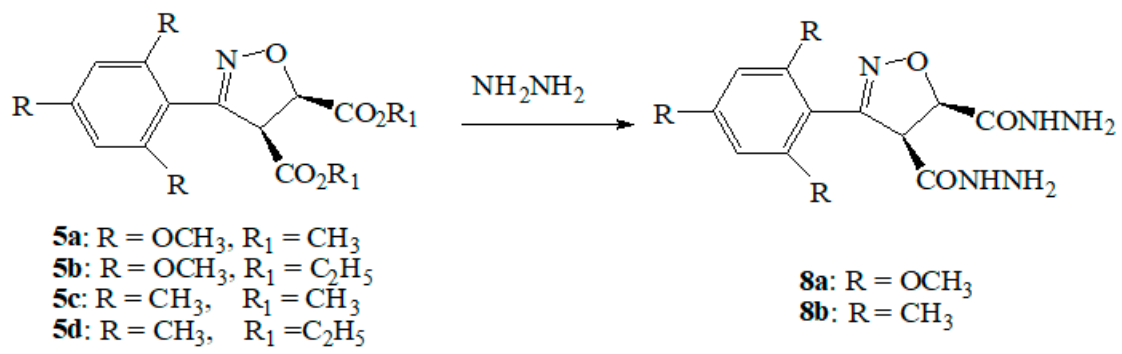

Scheme 4 . The synthesis of bis(hydrazinocarbonyl) derivatives $\mathbf{8} \mathbf{a}-\mathbf{b}$ by reaction of the isoxazoline derivatives with hydrazine hydrate.

Isoxazoline derivatives exhibit biological and pharmaceutical activities. They also have wide industrial and analytical applications [1-8,13]. These observations prompted us to study the synthesis of certain compounds that possess the isoxazoline moiety to study the antibacterial and antioxidant activities of these compounds on different bacterial strains.

\section{Results and Discussion}

Compound 9 was prepared from the reaction of trans-3-(2,4,6-trimethoxyphenyl)-4,5-dihydro4,5-bis(hydrazinocarbonyl)isoxazole (8a) with phenylisothiocyanate in absolute ethanol at room temperature; Scheme 5. 
<smiles>COc1cc(OC)c(/C=N/O)c(OC)c1</smiles><smiles>COc1cc(OC)c(C2=NO[C@@H](C(C)=O)[C@H]2C(C)=O)c(OC)c1</smiles>

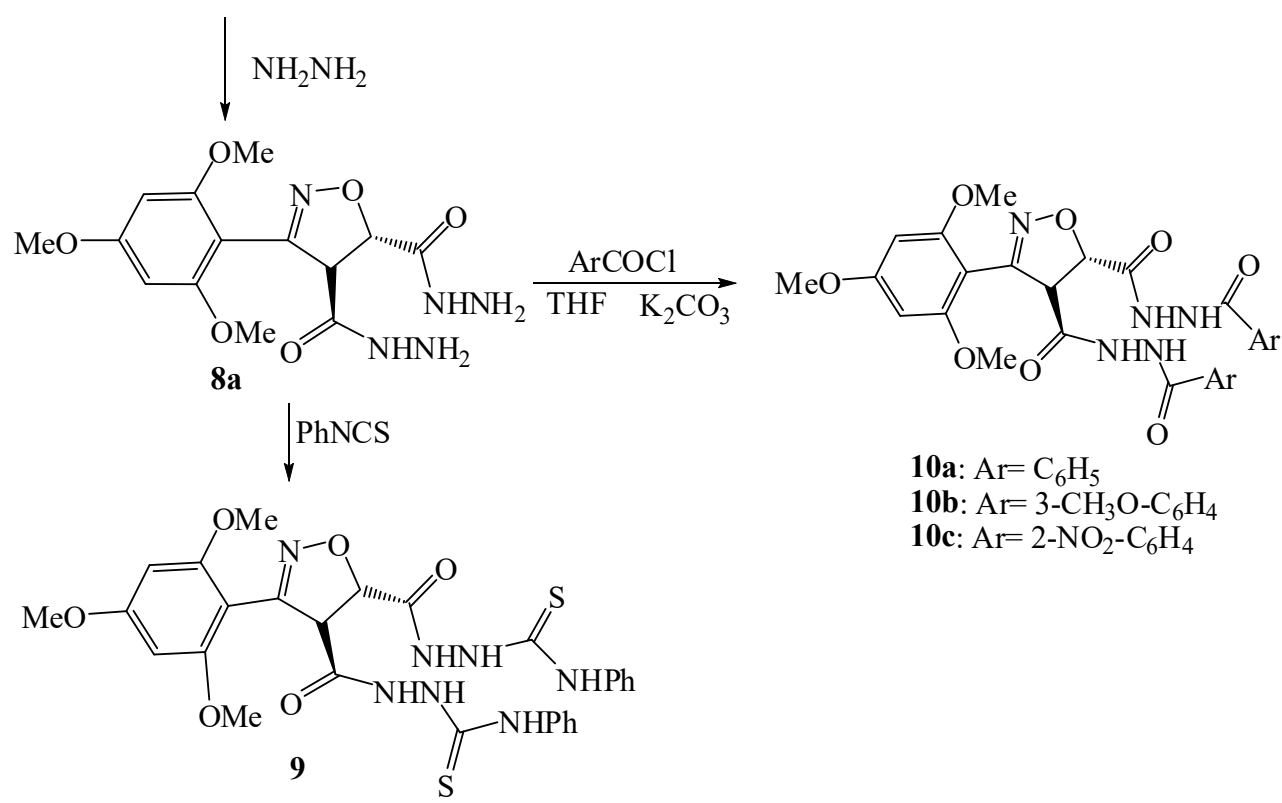

Scheme 5. The synthesis of the target isoxazoline derivatives 9 and $10 a-c$.

The High resolution mass spectrometry (HRMS) for compound 9 displays a molecular ion peak at $m / z=622.16207$ corresponding to the ion $\left[\mathrm{C}_{28} \mathrm{H}_{29} \mathrm{~N}_{7} \mathrm{O}_{6} \mathrm{~S}_{2}-\mathrm{H}\right]^{-}$, as expected from its calculated $m / z=622.15425$. The IR spectrum of the thiosemicarbazides derivative 9 shows absorption bands in the range $3028-3363 \mathrm{~cm}^{-1}$, which are assigned to the N-H stretching frequency. The band at $1703 \mathrm{~cm}^{-1}$ is assigned to the carbonyl group, while the band in the range $1200-1256 \mathrm{~cm}^{-1}$ corresponds to the thiocarbonyl group. The ${ }^{1} \mathrm{H}-\mathrm{NMR}$ spectrum for compound 9 shows peaks in the range $9.75-10.52 \mathrm{ppm}$, which belong to the NH protons. These protons are deuterium exchangeable-the ten aromatic protons are detected as a multiplet in the range 7.15-7.44 ppm, and the other two phenyl protons appear as a singlet at $6.20 \mathrm{ppm}$. The protons on carbon atoms 4 and 5 of the isoxazoline ring appear as two doublets at 4.85 and $5.40 \mathrm{ppm}$, with a coupling constant of $7.8 \mathrm{~Hz}$. The NH peaks were confirmed upon addition of deuterium oxide to the NMR tubes of compound 9.

The ${ }^{13} \mathrm{C}-\mathrm{NMR}$ spectrum of compound 9 shows the carbon signal of $\mathrm{C}=\mathrm{O}$ groups at 159 and $162 \mathrm{ppm}$. The signal at $180 \mathrm{ppm}$ is assigned to the carbon in $\mathrm{C}=\mathrm{S}$ bond-ten aromatic carbons were observed in the range 124-128 ppm. The quaternary carbons in the aromatic rings appear at $138 \mathrm{ppm}$.

\subsection{Preparation of trans-3-(2,4,6-Trimethoxyphenyl)-4,5-dihydroisoxazolo-4,5-bis(phenylcarbohydrazide) 10a-c}

Compounds $\mathbf{1 0 a}-\mathbf{c}$ were prepared from the reaction of trans-3-(2,4,6-trimethoxyphenyl)-4,5dihydro-4,5-bis(hydrazinocarbonyl)isoxazole 8a with two equivalents of aroyl chloride derivatives, 
as shown in Scheme 1. The dicarbohydrazides 10a-c were characterized by the IR, ${ }^{1} \mathrm{H}-\mathrm{NMR},{ }^{13} \mathrm{C}-\mathrm{NMR}$, and HR-MS.

The HRMS for compound 10a displays a molecular ion peak at $m / z=560.17793$ corresponding to the ion $\left[\mathrm{C}_{28} \mathrm{H}_{26} \mathrm{~N}_{5} \mathrm{O}_{8}-\mathrm{H}\right]^{-}$, as expected from its calculated $m / z=560.17814$. The IR spectrum shows a broad band in the range $3008-3306 \mathrm{~cm}^{-1}$, which is assigned to the $\mathrm{NH}$ stretching frequency. The band at $1650 \mathrm{~cm}^{-1}$ indicates the amide carbonyl group. In compound $10 \mathrm{c}$, the band at $1535 \mathrm{~cm}^{-1}$ corresponds to the nitro $\left(\mathrm{NO}_{2}\right)$ group.

It can be seen from the ${ }^{1} \mathrm{H}-\mathrm{NMR}$ spectra of compound $10 \mathrm{a}-\mathrm{c}$ that the three methoxy groups appear as two singlets-one at $3.76 \mathrm{ppm}$ corresponds to six protons, and it belongs to the methoxy at the ortho positions of the phenyl group, while the singlet at $3.79 \mathrm{ppm}$ corresponds to the protons of the methoxy group in the para position. The two protons on carbon atoms 4 and 5 of the isoxazoline ring appear as two doublets at 5.02 and $5.31 \mathrm{ppm}$, with a coupling constant of $7.8 \mathrm{~Hz}$. The two protons of the aryl group appear at $6.32 \mathrm{ppm}$ as a singlet. Compound 10a has ten aromatic protons as a multiplet in the range 6.93-7.97 ppm, according to the ${ }^{1} \mathrm{H}-\mathrm{NMR}$ spectrum. The broad peak in the range $10.27-10.59 \mathrm{ppm}$ is assigned to the four $\mathrm{NH}$ amide protons.

The ${ }^{1} \mathrm{H}-\mathrm{NMR}$ spectra of compound $\mathbf{1 0 b}$ shows a single peak at $3.83 \mathrm{ppm}$, which corresponds to the protons of the two methoxy groups in the meta position on the benzoyl rings, and eight aromatic protons appear as a multiplet in the range $7.11-7.50 \mathrm{ppm}$. The broad peak in the range 10.22-10.53 ppm is assigned to the four $\mathrm{NH}$ amide protons, while ${ }^{1} \mathrm{H}-\mathrm{NMR}$ spectrum of compound 10c shows eight aromatic protons as a multiplet in the range $7.60-8.12 \mathrm{ppm}$. Three singlets in the range 10.57-10.81 ppm are assigned to the four $\mathrm{NH}$ amide protons. The ${ }^{13} \mathrm{C}-\mathrm{NMR}$ spectra of the compounds 10a-c, show signals at 55.3 and $55.5 \mathrm{ppm}$, which are assigned to the three methoxy carbons on the phenyl group; the signal at $90 \mathrm{ppm}$ is assigned to the two $\mathrm{CH}$ aromatic carbons. The $\mathrm{C}=\mathrm{O}$ carbons appear at $164-167 \mathrm{ppm}$. For compound 10a, the aromatic carbons in the two benzoyl rings appear in the range 124-139 ppm, while in compound $\mathbf{1 0 b}$, the aromatic carbons appear in the range 112-133 ppm. The two methoxy groups attached to the benzoyl ring appear at $55.2 \mathrm{ppm}$. In compound 10c, signals at 146 and $147 \mathrm{ppm}$ are assigned to the carbons attached to the nitro group - other aromatic carbons appear in the range 124-133 ppm. The full assignments of ${ }^{13} \mathrm{C}-\mathrm{NMR}$ and ${ }^{1} \mathrm{H}-\mathrm{NMR}$ chemical shifts of compound $10 \mathrm{~b}$ were confirmed by HMQC and HMBC. The IR, ${ }^{1} \mathrm{H}-\mathrm{NMR}$ and ${ }^{13} \mathrm{C}-\mathrm{NMR}$ spectra of all the compounds are presented in the Supplementary Material.

\subsection{Antimicrobial Activity}

The antibacterial activities of the newly synthesized compounds were evaluated in vitro against three Gram-positive and three Gram-negative bacterial strains by agar well diffusion. The results of the in vitro antibacterial screen of new compounds are shown in Table 1. For compound 9, activity against four bacterial species was observed-Micrococcus luteus, Staphylococcus aureus, Serratia marcescens, and Bacillus cereus (Table 1)-whereas, for compounds 10a, 10b, and 10c, no activity was observed against all bacterial species.

Table 1. Antimicrobial activity of compounds 9, 10a, 10b, 10c against different Gram-positive and Gram-negative bacteria.

\begin{tabular}{ccccc}
\hline Bacterial Species & $\mathbf{9}$ & 10a & 10b & 10c \\
\hline Gram-positive bacteria & & & & \\
Micrococcus luteus (ATCC 9341)) & + & - & - & - \\
Staphylococcus aureus (ATCC 29213) & + & - & - & - \\
Bacillus cereus (ATCC 11778) & + & - & - & - \\
Gram-negative bacteria & & & & - \\
Serratia marcescens (ATCC 27117) & + & - & - & - \\
Pseudomonas aeruginosa (ATCC 27853) & - & - & - & - \\
Salmonella typhi (ATCC 6539) & - & - & - & - \\
\hline
\end{tabular}




\subsection{Antioxidant Activity}

The antioxidant activity from organic compounds plays an important role through free radical scavenging, which is useful in the treatment of many diseases. In this study, the free radical scavenging activity of all compounds was carried out in the presence of the DPPH (1,1-diphenyl-2-picrylhydrazyl) and ABTS (2'-azino-bis(3-ethylbenzoline-6-sulfonic acid) diammonium salt) using ascorbic acid and $\alpha$-Tocopherol antioxidant agents as a positive control. Although several methods are available for the determination of the antioxidant activity, the DPPH and ABTS methods are very common, rapid, and two of the most appropriate methods [14,15].

A series of concentrations ranging from $0.005-0.50 \mathrm{mg} / \mathrm{mL}$ were prepared and from each tested compound and then investigated for their antioxidant activity power using the different models. The results are summarized in Figure 1. The results indicated that the DPPH and ABTS radical scavenging activities were concentration dependent (Figure 1), and the order of radical scavenging power for both models was $9>10 c>10 b>10 a$.
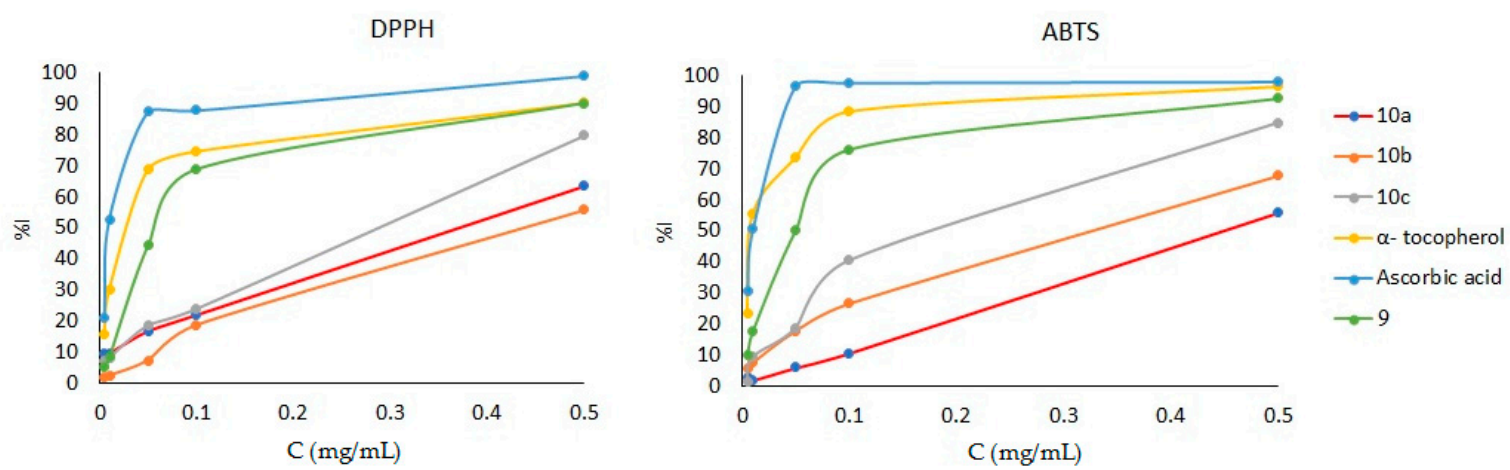

Figure 1. Antioxidant activity of compounds $9,10 a, 10 b, 10 c$, and positive controls (ascorbic acid and $\alpha$-tocopherol) by using DPPH (1,1-diphenyl-2-picrylhydrazyl) and ABTS (2'-azino-bis(3-ethylbenzoline6-sulfonic acid) diammonium salt) assays.

The IC50 (effective concentration for scavenging 50\% of the inhibition) of synthesized compounds on DPPH and ABTS radicals are presented in Table 2. Based on the experimental results, among all the compounds synthesized 9, 10a, 10b, and 10c showed higher scavenging activity towards DPPH and ABTS. The higher antioxidant activity of compound 9 can be explained by the existence of the thiourea fragment [16]. However, the order of the radical scavenging power found in both models was $10 c>10 b>10 a$ due to the fact that the presence of the nitro group on the phenyl in compound 10c determines a slight increase in antioxidant activity of compound 10c compared with 10b and 10a.

Table 2. DPPH and ABTS antioxidant activities of compounds 9, 10a, 10b, and 10c, and positive controls (ascorbic acid and $\alpha$-tocopherol). Values expressed are means \pm S.D. of three parallel measurements.

\begin{tabular}{ccc}
\hline Compound & $\begin{array}{c}\text { DPPH } \\
\text { IC50 }(\mathbf{m g} / \mathbf{m L})\end{array}$ & $\begin{array}{c}\text { ABTS } \\
\text { IC50 }(\mathbf{m g} / \mathbf{m L})\end{array}$ \\
\hline $\mathbf{9}$ & $0.07 \pm 4.7 \times 10^{-3}$ & $0.06 \pm 5.7 \times 10^{-3}$ \\
$\mathbf{1 0 a}$ & $0.20 \pm 3.0 \times 10^{-3}$ & $0.12 \pm 7.1 \times 10^{-3}$ \\
$\mathbf{1 0 b}$ & $0.17 \pm 8.3 \times 10^{-2}$ & $0.10 \pm 1.0 \times 10^{-2}$ \\
$\mathbf{1 0 c}$ & $0.09 \pm 1.9 \times 10^{-3}$ & $0.08 \pm 5.0 \times 10^{-3}$ \\
$\alpha$-Tocopherol & $2.3 \times 10^{-3} \pm 1.7 \times 10^{-5}$ & $1.8 \times 10^{-3} \pm 4.7 \times 10^{-6}$ \\
Ascorbic acid & $1.7 \times 10^{-3} \pm 2.3 \times 10^{-6}$ & $1.6 \times 10^{-3} \pm 4.7 \times 10^{-6}$ \\
\hline
\end{tabular}

Mean values are significantly different $(p<0.05)$. 


\section{Materials and Methods}

\subsection{Materials}

2,4,6-trimethoxybenzaldehyde, hydroxylammonium chloride, dimethyl fumarate, hydrazine hydrate, substituted benzoyl chloride, phenyl isothiocyanate, 1,1-diphenyl-1-picrylhydrazyl (DPPH, purity N 99\%), ascorbic acid (purity = 99\%), $\alpha$-tocopherol (purity = 99\%), 2,2'-azino-bis(3ethylbenzoline-6-sulfonic acid) diammonium salt (ABTS, purity N 99\%), organic solvents and reagents were purchased from Aldrich (St Louis, MO, USA), Fluka (Steinheim, Germany) and Across (Morris Plains, NJ, USA) and were used without any further purification. Melting points were measured on electrothermal digital melting point apparatus and were uncorrected. Infrared spectra (IR) were recorded over the range $400-4000 \mathrm{~cm}^{-1}$ on an FT-IR Spectrometer Across (Thermo Scientific, WI, USA) and Janssen, Bruker spectrum 2000 Across (Morris Plains, NJ, USA). Potassium bromide pellets were used. High-resolution mass spectra (HRMS) were measured in positive ion mode using the electrospray ionization (ESI) technique on the Bruker APEX-2 instrument Across (Bremen, Germany) and Janssen. Nuclear magnetic resonance spectra $\left({ }^{1} \mathrm{H}-\mathrm{NMR},{ }^{13} \mathrm{C}-\mathrm{NMR}\right.$ and $\left.2 \mathrm{DNMR}\right)$ were measured using Bruker Avance III (Finnigan Corp., San Jose, CA, USA). Spectra were acquired in $\left(\mathrm{CDCl}_{3}, 1 \% \mathrm{TMS}\right)$ or (DMSO- $d_{6}, 1 \%$ TMS)

\subsection{Preparation of 2,4,6-Trimethoxybenzaldoxime}

2,4,6-trimethoxybenzaldehyde $(11.7 \mathrm{~g}, 60 \mathrm{mmol})$ was dissolved in a $100 \mathrm{~mL}$ ethanol/NaOH $(10 \%)$ mixture (1:1 ratio). Excess hydroxylammonium chloride was dissolved in water $(75 \mathrm{~mL})$. Then, the two solutions were mixed and the mixture was heated at $60{ }^{\circ} \mathrm{C}$ for $30 \mathrm{~min}$. The mixture was then allowed to cool to room temperature. White crystals were collected by suction filtration and recrystallized from ethanol [17].

\subsection{Preparation of 2,4,6-Trimethoxybenzonitrile Oxide 1a}

2,4,6-trimethoxybenzaldoxime ( $4.8 \mathrm{~g}, 24 \mathrm{mmol}$ ) was dissolved in $\mathrm{NaOH}$ solution $(1 \mathrm{~N}, 50 \mathrm{~mL})$ and pyridine $(20 \mathrm{~mL})$. The clear solution was added dropwise with stirring for a period of $1 \mathrm{~h}$ to a previously prepared solution of $\mathrm{Br}_{2}(3.5 \mathrm{~g})$ in ice-cooled $1 \mathrm{~N} \mathrm{NaOH}(80 \mathrm{~mL})$. The temperature was maintained during the addition at $0{ }^{\circ} \mathrm{C}$. After the addition was completed, the resulting solution was stirred at $0{ }^{\circ} \mathrm{C}$ for a further $30 \mathrm{~min}$. The resulting white precipitate was filtrated as quickly as possible through a large Büchner funnel, washed several times with ice- $\mathrm{H}_{2} \mathrm{O}$, and dried under vacuum [18].

\subsection{Preparation of trans-Dimethyl 3-(2,4,6-trimethoxy phenyl)-4,5-dihydro-4,5-isoxazoledicarboxylate 5a}

Dimethyl fumarate $(2.2 \mathrm{~g}, 15 \mathrm{mmol})$ was added to a solution of 2,4,6-trimethoxybenzonitrile oxide $(3.15 \mathrm{~g}, 15 \mathrm{mmol})$ in dry tetrahydrofuran (THF) $(80 \mathrm{~mL})$. The mixture was heated under reflux for $6 \mathrm{~h}$. The solvent was removed using a rotatory evaporator and the residue was recrystallized from the methanol-petroleum ether $\left(60-80{ }^{\circ} \mathrm{C}\right)$ [19].

${ }^{1} \mathrm{H}-\mathrm{NMR}\left(400 \mathrm{MHz}, \mathrm{CDCl}_{3}\right): \delta \mathrm{ppm}=3.54(\mathrm{~s}, 6 \mathrm{H}), 3.70(\mathrm{~s}, 6 \mathrm{H}), 3.76(\mathrm{~s}, 3 \mathrm{H}), 4.73(\mathrm{~d}, 1 \mathrm{H}, J=6.8 \mathrm{~Hz}), 5.45$ $(\mathrm{d}, 1 \mathrm{H}, J=6.8 \mathrm{~Hz}), 6.05(\mathrm{~s}, 2 \mathrm{H}) .{ }^{13} \mathrm{C}-\mathrm{NMR}\left(100 \mathrm{MHz}, \mathrm{CDCl}_{3}\right): \delta \mathrm{ppm}=52.7,52.9,55.4,56.0,59.1,80.5$, $90.6,98.0,149.6,159.7,162.9,167.8,169.8$.

\subsection{Preparation of trans-3-(2,4,6-Trimethoxyphenyl)-4,5-dihydro-4,5-bis(hydrazenocarbonyl)isoxazole 8a}

An excess amount of hydrazine hydrate was added to a solution of trans-dimethyl 3-(2,4,6-trimethoxyphenyl)-4,5-dihydro-4,5-isoxazoledicarboxylate (1.5 g, $4.3 \mathrm{mmol}$ ) in ethanol (80 $\mathrm{mL})$. The mixture was heated under reflux for $50 \mathrm{~h}$. The solvent was removed, and the residue was recrystallized from the methanol-petroleum ether $\left(60-80^{\circ} \mathrm{C}\right)$ to yield the product $(1 \mathrm{~g}, 67 \%$ yield $)$; mp: $178-180{ }^{\circ} \mathrm{C}$. The HRMS displayed a molecular ion peak at $m / z 376.12275$ corresponding to the 
ion $\left[\mathrm{C}_{14} \mathrm{H}_{19} \mathrm{~N}_{5} \mathrm{O}_{6}+\mathrm{Na}\right]^{+}$as expected from its calculated $\mathrm{m} / \mathrm{z}=376.12330$. IR $\left(\mathrm{KBr} ; \mathrm{cm}^{-1}\right): 3300(\mathrm{~N}-\mathrm{H})$, 3050 (C-H arom), 2940 (C-H aliph), 1650 (C=O), 1600 (C=C), 1450 (C=N), 1100 (C-O).

${ }^{1} \mathrm{H}-\mathrm{NMR}\left(400 \mathrm{MHz}, \mathrm{DMSO}-d_{6}\right): \delta \mathrm{ppm}=3.71(\mathrm{~s}, 6 \mathrm{H}), 3.80(\mathrm{~s}, 3 \mathrm{H}), 4.29\left(\mathrm{bs}, 4 \mathrm{H}, \mathrm{NH}_{2}\right), 4.50(\mathrm{~d}, 1 \mathrm{H}$, $J=6.8 \mathrm{~Hz}), 5.05(\mathrm{~d}, 1 \mathrm{H}, J=6.8 \mathrm{~Hz}), 6.23(\mathrm{~s}, 2 \mathrm{H}), 9.14(\mathrm{bs}, 1 \mathrm{H}, \mathrm{NH}), 9.50(\mathrm{bs}, 1 \mathrm{H}, \mathrm{NH}) .{ }^{13} \mathrm{C}-\mathrm{NMR}(100 \mathrm{MHz}$, DMSO- $\left.d_{6}\right): \delta \mathrm{ppm}=55.4,55.9,58.7,81.3,90.9,97.7,150.5,159.4,162.2,165.8,166.9$.

3.6. Preparation of

trans-3-(2,4,6-Trimethoxyphenyl)4,5-dihydroisoxazolo-4,5-bis[carbonyl-(4' phenyl)thiosemicarbazide] 9

Phenyl isothiocyanate $(0.82 \mathrm{~g}, 6 \mathrm{mmol})$ was added to a solution of hydrazinocarbonyl $(3.1 \mathrm{~g}$, $5 \mathrm{mmol})$ in absolute ethanol $(30 \mathrm{~mL})$. The reaction mixture was stirred at room temperature for approximately $20 \mathrm{~h}$. The mixture was poured into cold water. The resulting precipitate was filtered and recrystallized from ethanol, affording $2.5 \mathrm{~g}(80 \%)$ of product $9 ; \mathrm{mp}: 192-194{ }^{\circ} \mathrm{C}, \mathrm{IR}\left(\mathrm{KBr} ; \mathrm{cm}^{-1}\right)$ : 3028-3363 (N-H), 1703 (C=O), 1200-1256 (C=S).

${ }^{1} \mathrm{H}-\mathrm{NMR}\left(400 \mathrm{MHz}\right.$, DMSO- $\left.d_{6}\right): \delta \mathrm{ppm}=3.72(\mathrm{~s}, 6 \mathrm{H}), 3.74(\mathrm{~s}, 2 \mathrm{H}), 4.85(\mathrm{~d}, 1 \mathrm{H}, \mathrm{J}=7.8 \mathrm{~Hz}), 5.40(\mathrm{~d}, 1 \mathrm{H}$, $J=7.8 \mathrm{~Hz}), 6.20(\mathrm{~s}, 2 \mathrm{H}), 7.15-7.44(\mathrm{~m}, 10 \mathrm{H}), 9.75(\mathrm{bs}, 4 \mathrm{H}, \mathrm{NH}), 10.34(\mathrm{bs}, 1 \mathrm{H}, \mathrm{NH}), 10.52(\mathrm{bs}, 1 \mathrm{H}, \mathrm{NH})$. ${ }^{13} \mathrm{C} \mathrm{NMR}\left(100 \mathrm{MHz}, \mathrm{DMSO}-d_{6}\right): \delta \mathrm{ppm}=55.3,56.0,58.1,81.6,91.0,97.3,124.1,125.2,125.8,128.0,128.2$, $138.6,138.8,139.0,150.5,159.4,162.4,180.3$.

\subsection{Preparation of trans-3-(2,4,6-Trimethoxyphenyl)-4,5-dihydroisoxazolo-4,5-bis(aroylcarbohydrazide) 10a-c}

To a solution of acid dihydrazide $(1.12 \mathrm{~g}, 2 \mathrm{mmol})$ and potassium carbonate $(4 \mathrm{mmol})$ in aq.

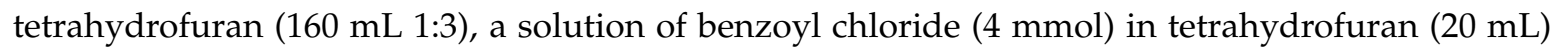
was added dropwise with stirring at $25^{\circ} \mathrm{C}$. The reaction mixture was stirred for $3-6 \mathrm{~h}$, during which time a precipitate was formed. The precipitate was collected by filtration and washed with water, then recrystallized from dimethylsulfoxide (DMSO)/water (1:1).

For compound 10a, trans-3-(2,4,6-trimethoxyphenyl)-4,5-dihydroisoxazolo-4,5bis(phenylcarbohydrazide):

Yield: $1.48 \mathrm{~g}(83 \%)$; mp: $202-204{ }^{\circ} \mathrm{C}$, the HRMS displayed a molecular ion peak at $\mathrm{m} / \mathrm{z} 560.17869$ corresponding to the ion $\left[\mathrm{C}_{28} \mathrm{H}_{27} \mathrm{~N}_{5} \mathrm{O}_{8}-\mathrm{H}\right]^{-}$, as expected from its calculated $\mathrm{m} / \mathrm{z}=560.17814$. IR $\left(\mathrm{KBr} ; \mathrm{cm}^{-1}\right)$ : $3145(\mathrm{~N}-\mathrm{H}), 3026$ (C-H aromatic), $1675(\mathrm{C}=\mathrm{O}), 1471(\mathrm{C}=\mathrm{N})$.

${ }^{1} \mathrm{H}-\mathrm{NMR}\left(400 \mathrm{MHz}\right.$, DMSO- $\left.d_{6}\right): \delta \mathrm{ppm}=3.41(\mathrm{~s}, 6 \mathrm{H}), 3.83(\mathrm{~s}, 3 \mathrm{H}), 5.02(\mathrm{~d}, 1 \mathrm{H}, J=7.8 \mathrm{~Hz}), 5.31(\mathrm{~d}, 1 \mathrm{H}$, $J=7.8 \mathrm{~Hz}), 6.32$ (s, 2H), 6.93-7.97 (m, 10H), 10.27 (bs, 1H, NH),10.44 (bs, 1H, NH), 10.59 (bs, 2H, NH). ${ }^{13} \mathrm{C}-\mathrm{NMR}\left(100 \mathrm{MHz}\right.$, DMSO- $\left.d_{6}\right): \delta \mathrm{ppm}=55.4,55.9,58.2,81.4,91.0,97.5,124.9,127.4,127.5,128.3,128.5$, $131.7,131.9,132.3,132.4,139.2,150.2,159.6,162.3,165.0,165.2,166.3,167.4$.

For compound 10b, trans-3-(2,4,6-trimethoxyphenyl)-4,5-dihydroisoxazolo-4,5bis(aroylcarbohydrazide):

Yield: $0.86 \mathrm{~g}(73 \%)$; mp: $225-227^{\circ} \mathrm{C}$. IR $\left(\mathrm{KBr} ; \mathrm{cm}^{-1}\right)$ : $3145(\mathrm{~N}-\mathrm{H}), 3026$ (C-H aromatic), 1675 (C=O), $1471(\mathrm{C}=\mathrm{N})$.

${ }^{1} \mathrm{H}-\mathrm{NMR}\left(400 \mathrm{MHz}, \mathrm{DMSO}-d_{6}\right): \delta \mathrm{ppm}=3.76(\mathrm{~s}, 6 \mathrm{H}), 3.79(\mathrm{~s}, 3 \mathrm{H}), 3.83(\mathrm{~s}, 6 \mathrm{H}), 4.97(\mathrm{~d}, 1 \mathrm{H}, J=7.8 \mathrm{~Hz})$, $5.24(\mathrm{~d}, 1 \mathrm{H}, J=7.8 \mathrm{~Hz}), 6.27(\mathrm{~s}, 2 \mathrm{H}), 7.11-7.50(\mathrm{~m}, 8 \mathrm{H}), 10.22(\mathrm{bs}, 1 \mathrm{H}, \mathrm{NH}), 10.37(\mathrm{bs}, 1 \mathrm{H}, \mathrm{NH})$, $10.53(\mathrm{bs}, 2 \mathrm{H}, \mathrm{NH}) .{ }^{13} \mathrm{C}-\mathrm{NMR}\left(100 \mathrm{MHz}, \mathrm{DMSO}-d_{6}\right): \delta \mathrm{ppm}=55.2,55.3,55.4,55.9,58.2,81.5,91.0,97.5$, $112.4,112.4,117.8,119.7,119.7,129.5,129.7,133.7,133.7,150.2,159.0,159.2,159.6,162.3,164.7,163.9$, 166.4, 167.3 .

For compound 10c, trans-3-(2,4,6-trimethoxyphenyl)-4,5-dihydroisoxazolo-4,5bis(aroylcarbohydrazide):

Yield: $0.63 \mathrm{~g}(52 \%)$ of product; mp: $255-257^{\circ} \mathrm{C}$, IR $\left(\mathrm{KBr} ; \mathrm{cm}^{-1}\right)$ : $3145(\mathrm{~N}-\mathrm{H}), 3026$ (C-H aromatic), $1608(\mathrm{C}=\mathrm{O}), 1471(\mathrm{C}=\mathrm{N}), 1535\left(\mathrm{NO}_{2}\right)$. 
${ }^{1} \mathrm{H}-\mathrm{NMR}\left(400 \mathrm{MHz}, \mathrm{DMSO}-d_{6}\right): \delta \mathrm{ppm}=3.74(\mathrm{~s}, 6 \mathrm{H}), 3.80(\mathrm{~s}, 3 \mathrm{H}), 4.93(\mathrm{~d}, 1 \mathrm{H}, J=7.8 \mathrm{~Hz}), 5.28(\mathrm{~d}, 1 \mathrm{H}$, $J=7.8 \mathrm{~Hz}), 6.24(\mathrm{~s}, 2 \mathrm{H}), 7.60-8.12(\mathrm{~m}, 8 \mathrm{H}), 10.57$ (bs, 1H, NH), 10.61 (bs, 1H, NH), 10.81 (bs, 2H, NH).

${ }^{13} \mathrm{C}-\mathrm{NMR}\left(100 \mathrm{MHz}\right.$, DMSO- $\left.d_{6}\right): \delta=55.3,55.9,58.2,81.2,90.8,97.4,124.2,124.3,129.5,129.5,130.1$, $130.3,131.3,131.7,146.9,147.2,150.2,159.5,162.3,163.7,164.0,165.7,166.8$.

\subsection{Antimicrobial Activity}

In vitro antimicrobial activity of new compounds was screened against six different bacterial isolates (obtained from the Department of Biological Sciences, Yarmouk University, Jordan) using the agar well diffusion methods. The six bacterial isolates investigated included three Gram-positive bacteria Micrococcus luteus, Bacillus cereus, and Salmonella typhi and three Gram-negative bacteria Staphylococcus aureus, Serratia marcescens, and Pseudomonas aeruginosa. Bacterial strains were cultured overnight at $37^{\circ} \mathrm{C}$ in tryptone soy broth (TSA).

\subsection{Antioxidant Activity}

The antioxidant activity of the compound was determined using the DPPH and ABTS according to the procedures described in the literature [19-22]. Positive controls used included $\alpha$-tocopherol and ascorbic acid, while methanol was the negative control. All determinations of the $\mathrm{IC}_{50}$ by the three assay methods were conducted in triplicate. The $\mathrm{IC}_{50}$ of the extracts and the positive controls, expressed as mean $\pm \mathrm{SD}$, are shown in Table 2. All determinations of the $\mathrm{IC}_{50}$ by the three assay methods were conducted in triplicate.

\section{Conclusions}

New 2-isoxazoline derivatives were successfully synthesized and characterized using spectroscopic techniques (IR and NMR) and elemental analysis. All the synthesized compounds have been investigated for their antioxidant activity by DPPH and ABTS assays, and the results indicated that these compounds have good scavenging activities. They were evaluated for their antimicrobial activities against certain Gram-positive and Gram-negative bacteria. The results show that compound 9 has activity against certain bacterial species, whereas the remainder of the compounds have no considerable effects on microbial growth.

Supplementary Materials: The following are available online, Figure S1: IR ( $\mathrm{KBr}$ disk) spectrum for compound 9, Figure S2: ${ }^{1} \mathrm{H}-\mathrm{NMR}$ spectrum of compound 9 in DMSO- $d_{6}$ Solvent, Figure S3: ${ }^{13} \mathrm{C}-\mathrm{NMR}$ spectrum of compound 9 in DMSO- $d_{6}$ Solvent, Figure S4: IR (KBr disk) spectrum for compound 10b, Figure S5: IR (KBr disk) spectrum for compound 10c, Figure S6: ${ }^{1} \mathrm{H}-\mathrm{NMR}$ spectrum of compound 10a in DMSO- $d_{6}$ Solvent, Figure S7: ${ }^{1} \mathrm{H}-\mathrm{NMR}$ spectrum of compound 10b in DMSO- $d_{6}$ Solvent, Figure S8: ${ }^{1} \mathrm{H}-\mathrm{NMR}$ spectrum of compound 10c in DMSO- $d_{6}$ Solvent, Figure S9: ${ }^{13} \mathrm{C}-\mathrm{NMR}$ spectrum of compound 10a in DMSO- $d_{6}$ Solvent, Figure S10: ${ }^{13} \mathrm{C}-\mathrm{NMR}$ spectrum of compound 10b in DMSO- $d_{6}$ Solvent, Figure S11: ${ }^{13} \mathrm{C}-\mathrm{NMR}$ spectrum of compound 10c in DMSO- $d_{6}$ Solvent, Figure S12: HMQC spectrum of compound 10b in DMSO- $d_{6}$ Solvent, Figure S13: HMBC spectrum of compound 10b in DMSO- $d_{6}$ Solvent.

Author Contributions: M.A.-Q., L.A.-M. and S.A.-O. conceived and designed the experiments, analyzed the data, and prepared the manuscript. A.A. and F.H. performed the experiments, analyzed the data and prepared the manuscript. All authors have read and agreed to the published version of the manuscript.

Funding: We would like to thank the Deanship of Scientific Research and Graduate Studies at Yarmouk University for funding this research project. and the Deanship of Scientific Research and Post Graduate Studies at the University of Ha'il, Saudi Arabia.

Conflicts of Interest: The authors declare no conflict of interest. 


\section{References}

1. Jung, H.K.; Doddareddya, M.R.; Cha, J.H.; Rhim, H.; Cho, Y.S.; Koh, H.Y.; Jung, B.Y.; Pae, A.N. Synthesis and biological evaluation of novel T-type $\mathrm{Ca}^{2+}$ channel blockers. Bioorg. Med. Chem. 2004, 12, 3965-3970. [CrossRef] [PubMed]

2. Popat, K.H.; Nirmavat, K.S.; Kachhadia, V.V.; Joshi, H.S. Synthesis and biological activity of 3-aryl-5-(3'-bromo/chlorophenyl) isoxazoles. J. Indian Chem. Soc. 2003, 80, 707-708. [CrossRef]

3. Norman, B.H.; Lander, P.A.; Gruber, J.M.; Kroin, J.S. Cyclohexyl-linked tricyclic isoxazoles are potent and selective modulators of the multidrug resistance protein (MRP1). Bioorg. Med. Chem. Lett. 2005, 15, 5526-5530. [CrossRef] [PubMed]

4. Nyati, M.; Rao, S.N.; Srivastav, K.Y.; Verma, L.B. Microwave induced synthesis and antimicrobial activity of some 3-benzimidazolyl-5 aryl-2-isoxazolines. Indian J. Heterocycl. Chem. 2006, 15, 295-296.

5. Diana, G.D.; McKinlay, M.A.; Brisson, C.J.; Zalay, E.S.; Miralles, J.V.; Salvador, U.J. Isoxazoles with antipicornavirus activity. J. Med. Chem. 1985, 28, 748-752. [CrossRef] [PubMed]

6. Kiran Kumar, A.B.V.; Uma Ravi Sankar, A.; Kim, S.H. A simple, efficient one-pot synthesis of 2-isoxazoline derivatives and their antimicrobial activity. J. Heterocycl. Chem. 2014, 51 (Suppl. S1), E146-E151. [CrossRef]

7. Prajapti, S.K.; Shrivastava, S.; Bihade, U.; Gupta, A.K.; Naidu, V.G.M.; Banerjee, U.C.; Babu, B.N. Synthesis and biological evaluation of novel $\Delta 2$-isoxazoline fused cyclopentane derivatives as potential antimicrobial and anticancer agents. MedChemComm 2015, 6, 839-845. [CrossRef]

8. Antczak, C.; Bauvois, B.; Monneret, C.; Florent, J.C. A new acivicin prodrug designed for tumor-targeted delivery. Bioorg. Med. Chem. 2001, 9, 2843-2848. [CrossRef]

9. Abu-Orabi, S.T.; Al-Ghezawi, N.M. 1, 3-Dipolar cycloaddition of nitrile oxides with cis-and trans-ethylene-substituted. DELTA. 2-isoxazoline derivatives. J. Chem. Eng. Data 1987, 32, 383-384. [CrossRef]

10. Abu-Orabi, S.T. 1,3-Dipolar cycloaddition reactions of substituted benzyl azides with acetylenic compounds. Molecules 2002, 7, 302-314. [CrossRef]

11. Abu-Orabi, S.T. 1,3 Dipolar cycloaddition reactions of aromatic nitrile oxides with disubstituted acetylenes and disubstituted ethylenes. Part IV. Mutah J. Res. Stud. Nat. Appl. Sci. Ser. 1995, 10, 79-88.

12. Abu-Orabi, S.T.; Al-Hamdany, R.; Al-Momany, L.A.; Ta'an, E.A. Reactions of isoxazoline and isoxazole derivatives with hydraaaazine hydrate. Asian J. Chem. 1999, 11, 1276.

13. Koparir, M.; Orek, C.; Parlak, A.E.; Söylemez, A.; Koparir, P.; Karatepe, M.; Dastan, S.D. Synthesis and biological activities of some novel aminomethyl derivatives of 4-substituted-5-(2-thienyl)-2,4-dihydro-3H1,2,4-triazole-3-thiones. Eur. J. Med. Chem. 2013, 63, 340-346. [CrossRef]

14. Tarawneh, A.H.; Al-Momani, L.A.; León, F.; Jain, S.K.; Gadetskaya, A.V.; Abu-Orabi, S.T.; Tekwani, B.L.; Cutler, S.L. Evaluation of triazole and isoxazole derivatives as potential anti-infective agents. Med. Chem. Res. 2018, 27, 1269-1275. [CrossRef]

15. Kumar, A.; Sharma, P.; Kumari, P.; Kalal, B.L. Exploration of antimicrobial and antioxidant potential of newly synthesized 2, 3-disubstituted quinazoline-4(3H)-ones. Bioorg. Med. Chem. Lett. 2011, 21, 4353-4357. [CrossRef]

16. Yehye, W.A.; Rahman, N.A.; Alhadi, A.A.; Khaledi, H.; Ng, S.W.; Ariffin, A. Butylated hydroxytoluene analogs: Synthesis and evaluation of their multipotent antioxidant activities. Molecules 2012, 17, 7645-7665. [CrossRef]

17. Brewster, R.Q.; VanderWerf, C.A.; McEwen, W.E. Unitized Experiments in Organic Chemistry; Van Nostrand: New York, NY, USA, 1977; Volume 577.

18. Grundmann, C.; Dean, J.M. Nitrile Oxides. V. Stable aromatic nitrile oxides1, 2. J. Org. Chem. 1965, 30, 2809-2812. [CrossRef]

19. Al-Qudah, M.A.; Allahham, F.E.; Obeidat, S.M.; Al-Jaber, H.I.; Lahham, J.N.; Abu Orabi, S.T. In vitro antioxidant activities, total phenolics and total flavonoids of the different extracts of Capparis spinosa L. and capparis decidua Edgew (forssk.) from Jordan. Int. J. Pharm. Res. 2020, 12, 1226-1236.

20. Al-Qudah, M. Antioxidant acitvity and chemical composition of essential oils of fresh and air-dried Jordanian nepeta curviflora boiss. J. Biol. Act. Prod. Nat. 2016, 6, 101-111. 
21. Al-Qudah, M.A.; Saleh, A.M.; Alhawsawi, N.L.; Al-Jaber, H.I.; Rizvi, S.A.; Afifi, F.U. Composition, antioxidant and anticancer activities of the essential oil from fresh and air-dried aerial parts of Pallenis spinosa. Chem. Biodivers. 2017, 14, e1700146. [CrossRef] [PubMed]

22. Abu-Orabi, S.T.; Al-Qudah, M.A.; Saleh, N.R.; Bataineh, T.T.; Obeidat, S.M.; Al-Sheraideh, M.S.; Al-Jaber, H.I.; Tashtoush, H.I.; Lahham, J.N. Antioxidant activity of crude extracts and essential oils from flower buds and leaves of Cistus creticus and Cistus salviifolius. Arab. J. Chem. 2020, 13, 6256-6266. [CrossRef]

Sample Availability: Samples of the compounds are not available from the authors.

(C) 2020 by the authors. Licensee MDPI, Basel, Switzerland. This article is an open access article distributed under the terms and conditions of the Creative Commons Attribution (CC BY) license (http://creativecommons.org/licenses/by/4.0/). 